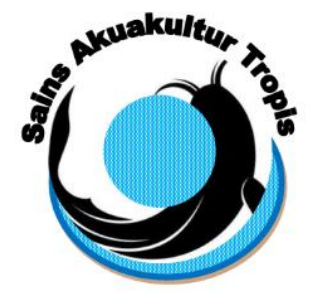

\author{
Jurnal Sains Akuakultur Tropis \\ Departemen Akuakultur \\ Fakultas Perikanan dan IImu Kelautan - Universitas Diponegoro \\ Jl. Prof. Soedarto, SH, Tembalang, Semarang $\mathbf{5 0 2 7 5}$ \\ Telp. (024) 7474698, Fax.: (024) 7474698 \\ Email: sainsakuakulturtropis@gmail.com, sainsakuakulturtropis@undip.ac.id
}

\title{
LAJU FILTRASI BAHAN ORGANIK OLEH KERANG HIJAU (Perna viridis) SEBAGAI BIOFILTER SERTA DAMPAKNYA TERHADAP PERTUMBUHAN DAN KELULUSHIDUPAN UDANG WINDU (Penaeus monodon)
}

\author{
Filtration Rate of Organic Matter by Green Mussel ( $\underline{\text { Perna viridis) }}$ ) as a Biofilter and the Impact on Growth and \\ Survival Rate of Tiger Shrimp ( \\ Diyah Retnosari, Sri Rejeki*), Titik Susilowati, Restiana Wisnu Ariyati \\ Departemen Akuakultur, \\ Fakultas Perikanan dan Ilmu Kelautan, \\ J1. Prof. Soedarto, SH, Tembalang, Semarang, Jawa Tengah -50275, Telp/Fax. +62247474698 \\ * Corresponding author: sri_rejeki7356@yahoo.co.uk
}

\begin{abstract}
ABSTRAK
Sisa pakan dan feses dalam budidaya udang windu (Penaeus monodon) yang terakumulasi menjadi sumber bahan organik dapat memicu peningkatan konsentrasi amonia $\left(\mathrm{NH}_{3}\right)$. Solusi untuk menurunkan kandungan bahan organik yaitu menggunakan kerang hijau (Perna viridis) sebagai biofilter. Kerang hijau sebagai hewan filter feeder dapat mengasimilasi bahan organik. Penelitian ini bertujuan untuk mengkaji laju filtrasi kerang hijau dalam menurunkan kandungan bahan organik yang berasal dari kepadatan udang windu yang berbeda dan mengkaji pertumbuhan serta kelulushidupan udang windu yang dibudidayakan dengan air hasil filtrasi kerang hijau. Biota uji yang digunakan adalah udang windu post larva 45 kepadatan $40 \mathrm{ekor} / \mathrm{m}^{2}$ dan kerang hijau ukuran $3-4 \mathrm{~cm}$ kepadatan 30 ekor $/ \mathrm{m}^{2}$. Penelitian ini menggunakan metode eksperimental dengan Rancangan Acak Lengkap (RAL) terdiri atas 3 perlakuan dengan 3 kali pengulangan, yaitu: A (kepadatan udang windu 20 ekor $/ \mathrm{m}^{2}$ ), B (kepadatan udang windu $60 \mathrm{ekor} / \mathrm{m}^{2}$ ), dan C (kepadatan udang windu $100 \mathrm{ekor} / \mathrm{m}^{2}$ ). Hasil penelitian menunjukkan bahwa bahan organik dari kepadatan udang windu yang berbeda tidak berpengaruh nyata $(\mathrm{P}>0,05)$ terhahap laju filtrasi (FR) kerang hijau dalam menurunkan kandungan bahan organik. Air limbah hasil filtrasi kerang hijau tidak berpengaruh nyata $(\mathrm{P}>0,05)$ terhahap pertumbuhan dan kelulushidupan udang windu. Laju filrasi perlakuan $\mathrm{A}$ berkisar antara -1,83-1,31L/hari, perlakuan B -2,07-0,96 L/hari, dan perlakuan C -2,03-1,06 L/hari. Penurunan bahan organik perlakuan A sebesar 44,92 mg/L, perlakuan B 36,58 mg/L, dan perlakuan C 39,84 mg/L. Laju

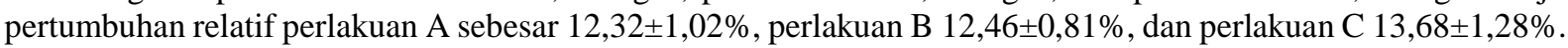

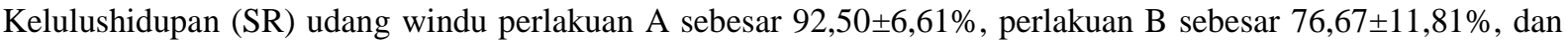

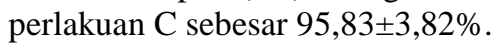

Kata kunci: bahan organik, kerang hijau, laju filtrasi, pertumbuhan, udang windu

\section{ABSTRACT}

The remains feed and feces in the cultivation of tiger shrimp (Penaeus monodon) which accumulates become a source of organic matter which can trigger an increase in ammonia $\left(\mathrm{NH}_{3}\right)$ concentration. The solution to reduce the organic matter content is to use green mussel ( $\underline{\text { Perna viridis) }}$ ) as biofilter. Green mussels as filter feeder animals can assimilate organic matter. This research was aims to examine the filtration rate of green mussels in reduced the organic matter that come from different densities of tiger shrimp and to examine the growth and survival rate of tiger shrimp which was cultivated with water that had been filtered by green mussels. The test biota used to tiger shrimp post larva 45 density of 40 individuals $/ \mathrm{m}^{2}$ and green mussels sized $3-4 \mathrm{~cm}$ density 30 shrimp $/ \mathrm{m}^{2}$. This research was used the Completely Randomized Design (CRD) with experimental method. This research also was used 5 treatments and 3 repetitions, that was A (density of tiger shrimp 20 individuals $/ \mathrm{m}^{2}$ ), B (density of tiger shrimp 60 individuals $/ \mathrm{m}^{2}$ ), and $C$ (density of tiger shrimp 100 individuals $/ \mathrm{m}^{2}$ ). The result of this research shows that organic matter that come from different densities of tiger shrimp gave no significant effect $(P>0.05)$ on the filtration rate $(F R)$ of green mussel in reducing organic matter content. Waste water from the density of different tiger shrimp that had been filtered by green mussels gave no significant effect $(P>0.05)$ on 
growth and survival rate of tiger shrimp. Filtration rate of treatment A ranged from $(-1,83)$ to $1,31 \mathrm{~L} /$ day, treatment $B$ (-2,07)-0,96 L/day, and treatment C (-2,03)-1,06 L/day, and decreasing organic matter treatment A was 44,92 $\mathrm{mg} / \mathrm{L}$, treatment $B 36,58 \mathrm{mg} / \mathrm{L}$, and treatment $C 39,84 \mathrm{mg} / \mathrm{L}$. The relative growth rate $(R G R)$ of tiger shrimp treatment $A$ was $12,32 \pm 1,02 \%$, treatment $B$ was $12,46 \pm 0,81 \%$, and treatment $C$ was $13,68 \pm 1,28 \%$. The survival rate (SR) of treatment $A$ was $92,50 \pm 6,61$, treatment $B$ was $76,67 \pm 11,81 \%$, and treatment $C$ was $95,83 \pm 3,82 \%$.

Keyword: organic matter, green mussel, filtration rate, growth, tiger shrimp

Article Received: 31-12-2018; Accepted: 21-01-2019

\section{PENDAHULUAN}

Budidaya udang windu (Penaeus monodon) terbagi dalam berbagai cara pengelolaan yaitu ekstensif, semi intensif, dan intensif. Pengelompokkan tersebut didasarkan pada padat penebaran benih udang (benur) dan teknologi budidaya yang diterapkan. Semakin tinggi padat tebar yang digunakan, semakin tinggi pula teknologi budidaya yang harus diterapkan baik yang berkaitan untuk meningkatkan kualitas lingkungan budidaya maupun input pakan (Budiardi et al., 2005).

Wulandari et al., (2015) menyatakan bahwa padat tebar yang tinggi mengakibatkan peningkatan limbah metabolik yang disebabkan oleh jumlah pakan yang berlebih. Sisa pakan akan mengendap di dasar tambak dan berubah menjadi senyawa toksik karena dapat mengakibatkan penurunan kualitas air. Peningkatan jumlah pakan yang tidak termakan akan memicu peningkatan bahan organik dan senyawa toksik yang dihasilkan yaitu nitrit $\left(\mathrm{NO}_{2}\right)$ dan amonia $\left(\mathrm{NH}_{3}\right)$.

Craba et al. (2007) menyatakan bahwa kegiatan budidaya menghasilkan bahan organik dan anorganik seperti amonia $\left(\mathrm{NH}_{3}\right)$, fosfor, dan karbon organik terlarut. Tingginya bahan organik dan anorganik di perairan dapat menyebabkan kerusakan lingkungan. Menurut Djunaedi et al. (2016) bahan organik yang berasal dari feses, hasil metabolisme, dan sisa pakan yang tidak termakan oleh udang dapat memicu peningkatan konsentrasi senyawa beracun seperti amonia $\left(\mathrm{NH}_{3}\right)$ di dalam media budidaya. Akumulasi bahan organik dapat menurun jika nilai oksigen terlarut (DO) tinggi. Oksigen terlarut digunakan oleh bakteri aerob, yaitu nitrosomonas dan nitrobacter untuk melakukan dekomposisi bahan organik. Menurut Palayukan et al. (2016) merununnya kualitas air pada lingkungan tambak disebabkan oleh tingginya kandungan bahan organik serta unsur hara dari sisa pakan yang berasal dari buangan air tambak. Buangan air tambak mengandung unsur hara yang tinggi yang berasal dari sisa pakan dan feses.

Limbah hasil budidaya meliputi amonia $\left(\mathrm{NH}_{3}\right)$, bahan organik, dan padatan tersuspensi. Limbah tersebut apabila tidak dikelola dan dibuang langsung ke lingkungan dapat menyebabkan kerusakan lingkungan. Salah satu teknologi yang dapat digunakan untuk memperbaiki kualitas limbah budidaya yaitu dengan menerapkan biofilter (Muslim, 2013). Tujuan digunakannya filter dalam perairan yaitu untuk memperbaiki kualitas air agar layak digunakan kembali. Fungsi filter yaitu untuk menjernihkan air, dan secara biologis berfungsi untuk menetralisir senyawa yang bersifat toksik. Adanya biofilter juga bertujuan untuk mengurangi dan menyerap bahan organik terlarut (Putra et al., 2016).

Salah satu langkah untuk mengurangi kandungan nitrogen pada limbah budidaya yakni dengan menerapkan sistem biofilter menggunakan kerang ataupun rumput laut. Kerang sebagai hewan filter feeder mengasimilasi POM (Particulate Organic Matter) yaitu fitoplankton pada tambak budidaya. Kerang juga menyaring partikel tambahan seperti feses ikan atau udang. Kerang secara tidak langsung memanfaatkan DIN (Dissolve Inorganic Nitrogen) melalui asimilasi fitoplankton untuk perumbuhannya (Hold dan Edwards, 2014). Salah satu hewan yang dapat tumbuh dengan baik di daerah yang memiliki masukan bahan organik tinggi adalah kerang hijau. Pakan utama kerang hijau ( $P$. viridis) adalah mikroalga, sedangkan pakan tambahannya berupa zat organik terlarut dan bakteri (Liliandari dan Aunurohim, 2013).

Penelitian ini dilakukan untuk mengetahui laju filtrasi kerang hijau ( $P$. viridis) dalam menurunkan kandungan bahan organik yang berasal dari air limbah budidaya udang windu ( $P$. monodon) dengan kepadatan berbeda. Penggunaan kerang hijau sebagai biofilter diharapkan dapat menurunkan kandungan bahan organik, sehingga toksisitas air berkurang. Hasil penelitian Fua dan La (2008) menunjukkan bahwa bioremediator kerang darah berperan penting dalam menurunkan tingkat pencemaran limbah organik tambak udang, sehingga dapat meningkatkan kualitas air tambak.

Penelitian ini bertujuan untuk mengkaji laju filtrasi kerang hijau ( $P$. viridis) dalam menurunkan kandungan bahan organik yang berasal dari kepadatan udang windu ( $P$. monodon) yang berbeda. Penelitian ini juga bertujuan untuk mengkaji pertumbuhan dan kelulushidupan udang windu ( $P$. monodon) yang dibudidayakan dengan air yang sudah difilter oleh kerang hijau (P. viridis). Penelitian ini dilaksanakan pada bulan April - Mei 2018 di Desa Tambakbulusan, Kecamatan Karangtengah, Kabupaten Demak.

\section{MATERI DAN METODE Materi}

Biota uji yang digunakan dalam penelitian ini adalah benur udang windu ( $P$. monodon) stadia PL (post larva) 45 dan kerang hijau dengan ukuran 3-4 cm. Padat tebar benur udang windu ( $P$. monodon) pada wadah 
perlakuan adalah 20, 60, dan 100 ekor $/ \mathrm{m}^{2}$, sedangkan padat tebar udang windu ( $P$. monodon) pada wadah pemeliharaan udang adalah 40 ekor $/ \mathrm{m}^{2}$. Benur udang windu ( $P$. monodon) yang digunakan berasal dari Balai Besar Perikanan Budidaya Air Payau (BBPBAP) Jepara. Padat tebar kerang hijau yang digunakan adalah 30 ekor $/ \mathrm{m}^{2}$. Benih kerang hijau yang digunakan berasal dari perairan Karangtengah, Kabupaten Demak.

Wadah uji yang digunakan dalam penelitian ini berupa kolam terpal sebanyak 27 buah dengan ukuran $1 \times 1 \times 1 \mathrm{~m}^{3}$ untuk menampung $700 \mathrm{~L}$ air. Media pemeliharaan yang digunakan dalam penelitian ini adalah air payau dengan salinitas 28-33 ppt. Pakan udang windu ( $P$. monodon) yang diberikan selama penelitian berupa pellet dengan kandungan protein $30 \%$.

\section{Metode}

Metode yang digunakan dalam penelitian ini adalah metode eksperimental. Rancangan percobaan yang digunakan dalam penelitian ini yaitu rancangan acak lengkap (RAL). Penelitian ini menggunakan 3 perlakuan dan setiap perlakuan diulang sebanyak 3 kali, adapun susunan perlakuannya adalah sebagai berikut :

Perlakuan A : Kepadatan udang windu (P. monodon) 20 ekor $/ \mathrm{m}^{2}$

Perlakuan B : Kepadatan udang windu (P. monodon) $60 \mathrm{ekor} / \mathrm{m}^{2}$

Perlakuan C : Kepadatan udang windu (P. monodon) $100 \mathrm{ekor} / \mathrm{m}^{2}$

Dasar penentuan kepadatan udang windu ( $P$. monodon) sebagai sumber bahan organik didasarkan pada penelitian Akhrari (2013). Penelitian tersebut menggunakan kepadatan udang windu (P. monodon) $32 \mathrm{ekor} / \mathrm{m}^{2}$, $64 / \mathrm{m}^{2}$, dan $96 \mathrm{ekor} / \mathrm{m}^{2}$ sebagai sumber amonia $\left(\mathrm{NH}_{3}\right)$, Nitrit $\left(\mathrm{NO}_{2}\right)$, dan Nitrat $\left(\mathrm{NO}_{3}\right)$ yang berbeda. Perbedaan kepadatan udang windu (P. monodon) yang digunakan diharapkan dapat menghasilkan bahan organik yang berbeda. Penelitian ini dilakukan selama 21 hari dan dilakukan dalam beberapa tahap meliputi tahap persiapan wadah dan media, persiapan dan penebaran biota uji, pemberian pakan, resirkulasi air, pengukuran kualitas air, dan sampling biota uji.

Wadah uji dibersihkan dan dicuci sebelum digunakan untuk penelitian. Wadah dikeringkan dan diisi substrat berupa tanah yang sudah dihomogenkan serta dikeringkan. Wadah tersebut diberi label dan ditempatkan sesuai dengan hasil pengacakan. Penebaran udang windu dan kerang hijau dilakukan pada malam hari dan pagi hari setelah shubuh. Kepadatan udang windu pada wadah perlakuan adalah 20, 60, dan 100 ekor/m ${ }^{2}$, sedangkan pada wadah pemeliharaan udang sebanyak 40 ekor $/ \mathrm{m}^{2}$. Kepadatan kerang hijau yang digunakan yaitu $30 \mathrm{ekor} / \mathrm{m}^{2}$ berdasarkan hasil penelitian Evania (2018). Pemberian pakan menggunakan metode fix feeding rate dengan frekuensi pemberian pakan sebanyak 3 kali sehari, yaitu pada pukul 07.00, 13.00, dan 19.00. Pakan udang windu pada wadah perlakuan diberikan sebanyak 5\% dari biomassa udang, sedangkan pakan udang windu pada wadah pemeliharaan udang sebanyak 3\% dari biomassa udang. Frekuensi pemberian pakan dan jumlah pakan mengacu penelitian Lante et al. (2015). Proses resirkulasi atau perputaran air dilakukan setiap seminggu sekali, yaitu pada hari ke 7, 14, dan 21 penelitian. Volume air diresirkulasi sebanyak 25\% dari total volume air. Jumlah air yang diresirkulasi mengacu pada penelitian Mangampa (2012). Resirkulasi air pada penelitian ini dapat dilihat pada gambar berikut.

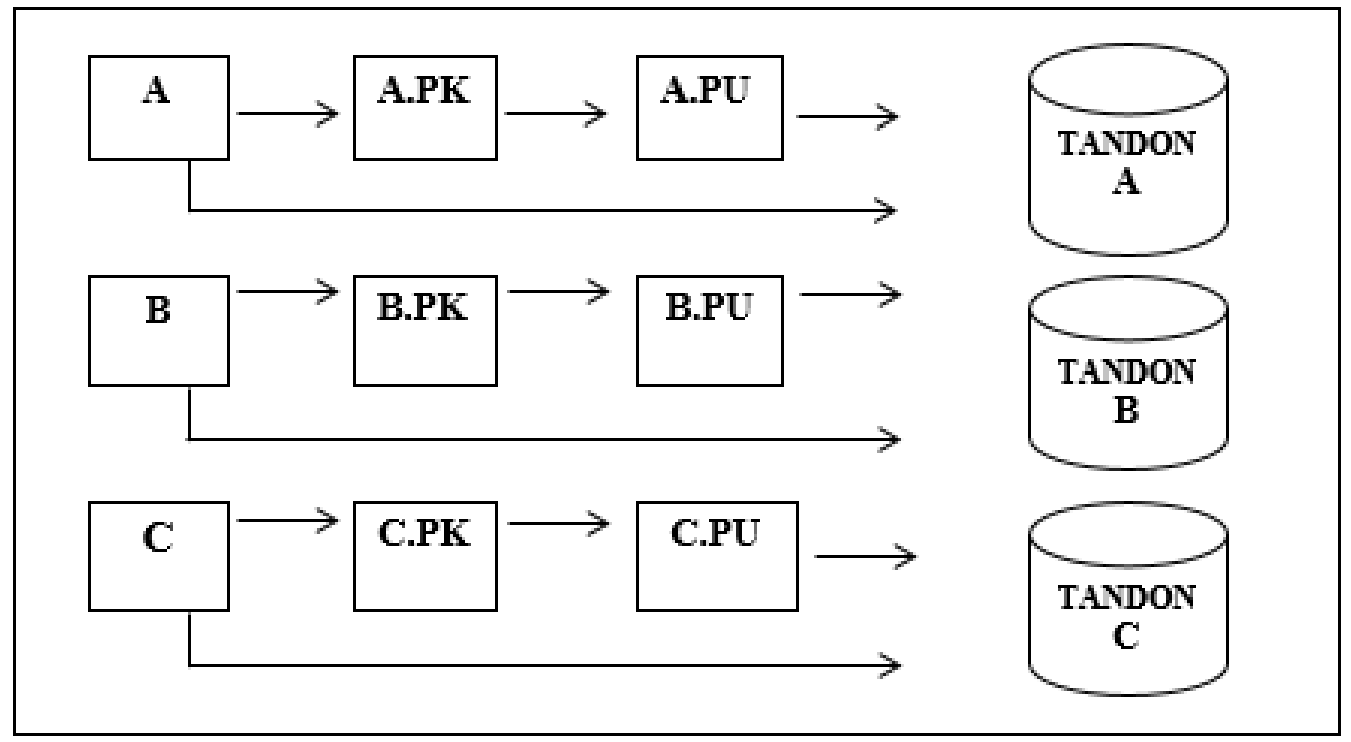

Keterangan :
A, B, dan C
P.K
$=$ Perlakuan kepadatan udang 20, 60, dan 100 ekor $/ \mathrm{m}^{2}$
P.U
$=$ Wadah pemeliharaan kerang hijau (biofilter)
$\longrightarrow$
$=$ Wadah pemeliharaan udang windu
$=$ Resirkulasi air 
Biota uji yang disampling meliputi udang windu ( $P$. monodon) dan kerang hijau $(P$. viridis). Udang windu (P. monodon) dan kerang hijau ( $P$. viridis) disampling sebanyak 10 ekor, dilakukan dengan cara ditimbang dan diukur panjangnya. Sampling udang windu dan kerang hijau dilakukan setiap seminggu sekali.

\section{Pengumpulan data}

Variabel yang diukur meliputi nilai laju filtrasi (FR) kerang hijau, laju pertumbuhan relatif (RGR) udang windu, kelulushidupan (SR) udang windu dan kerang hijau, dan pertumbuhan panjang mutlak kerang hijau.

\section{Laju filtrasi kerang hijau}

Rumus perhitungan laju filtrasi kerang hijau yang digunakan dalam penelitian menggunakan persamaan (Riisgard, 2001) sebagai berikut :

Keterangan :

$$
\mathrm{FR}=\left(\frac{\mathrm{V}}{\mathrm{nt}}\right) \ln \left(\frac{\mathrm{Co}}{\mathrm{Ct}}\right)
$$

$\mathrm{FR}=$ Laju filtrasi (L/hari), $\mathrm{V}=$ Volume media uji (L), $\mathrm{n}=$ Jumlah hewan uji (ekor), $\mathrm{t}=$ Waktu (hari), Co = Konsentrasi bahan organik awal $(\mathrm{mg} / \mathrm{L})$, dan $\mathrm{Ct}=$ Konsentrasi bahan organik akhir $(\mathrm{mg} / \mathrm{L})$.

\section{Laju pertumbuhan relatif (RGR)}

Menurut Takeuchi (1988), laju pertumbuhan relatif (RGR) udang dihitung dengan menggunakan rumus sebagai berikut :

$$
\mathrm{RGR}=\frac{\mathrm{W}_{\mathrm{t}}-\mathrm{W}_{\mathrm{o}}}{\mathrm{W}_{\mathrm{o}} \times \mathrm{t}} \times 100 \%
$$

Keterangan $: \mathrm{RGR}=$ Laju pertumbuhan relatif $(\%), \mathrm{Wt}=$ Bobot total udang pada akhir penelitian $(\mathrm{g})$, Wo $=$ Bobot total udang pada awal penelitian $(\mathrm{g})$, dan $\mathrm{t}=$ Lama penelitian (hari).

\section{Kelulushidupan/Survival rate (SR)}

Menurut Effendie (1997), kelulushidupan dapat dihitung menggunakan rumus sebagai berikut :

$$
\mathrm{SR}=\frac{\mathrm{N}_{\mathrm{t}}}{\mathrm{N}_{0}} \times 100 \%
$$

Keterangan : $\mathrm{SR}=$ kelulushidupan $(\%), \mathrm{N}_{\mathrm{t}}=$ jumlah biota uji pada akhir pemeliharaan (ekor), dan $\mathrm{N}_{\mathrm{o}}=$ jumlah biota uji pada awal pemeliharaan (ekor).

\section{Pertumbuhan panjang mutlak (GR)}

Menurut Effendie (1997), perhitungan nilai pertumbuhan atau pertambahan panjang mutlak kerang hijau (P. viridis) dapat dihitung dengan menggunakan rumus sebagai berikut :

$$
\mathrm{L}=\mathrm{Lt}-\mathrm{Lo}
$$

Keterangan : $\mathrm{L}=$ pertumbuhan panjang mutlak $(\mathrm{cm}), \mathrm{Lt}=$ panjang biota akhir pemeliharaan $(\mathrm{cm})$, dan $\mathrm{Lo}=$

\section{Kualitas air} panjang biota awal pemeliharaan $(\mathrm{cm})$.

Pengukuran suhu, $\mathrm{pH}$, salinitas, dan DO dilakukan setiap hari, sedangkan pengukuran amonia $\left(\mathrm{NH}_{3}\right)$, nitrat $\left(\mathrm{NO}_{3}\right)$, TOM air dan substrat, dan kelimpahan plankton dilakukan setiap seminggu sekali. Metode yang digunakan untuk mengukur kandungan amonia dan nitrat yaitu metode spektrofotometer, metode pengujian kadar bahan organik dalam tanah berdasarkan SNI 03-2831-1992, sedangkan metode yang digunakan untuk mengukur total bahan organik (TOM) di air dilakukan berdasarkan SNI-06-6989.22-2004. Pengukuran kelimpahan plankton dilakukan dengan menggunakan mikroskop.

\section{Analisis data}

Hasil data laju filtrasi kerang hijau ( $P$. viridis), laju pertumbuhan relatif (RGR) dan kelulushidupan (SR) udang windu ( $P$. monodon) dianalisis secara statistik. Data pertumbuhan panjang mutlak kerang hijau $(P$. viridis $)$, data kualitas air, dan kelulushidupan kerang hijau $(P$. viridis) dianalisis secara deskriptif. Sebelum data dianalisis ragam, dilakukan uji normalitas, uji homogenitas dan uji additivitas. Apabila pada ketiga uji tersebut menunjukkan data berdistribusi normal, bersifat homogen, dan aditif maka dilanjutkan dengan analisis ragam (ANOVA). Data dianalisis ragam (uji F) pada taraf kepercayaan 95\%. Jika analisis ragam diperoleh hasil yang berbeda nyata $(\mathrm{P}<0,05)$, maka dilakukan uji wilayah ganda Duncan untuk mengetahui perbedaan antar perlakuan.

\section{HASIL}

\section{Laju filtrasi (FR) kerang hijau}

Hasil pengukuran total organik matter (TOM) pada wadah perlakuan (kepadatan udang windu 20, 60, dan 100 ekor $/ \mathrm{m}^{2}$ ) tersaji pada Tabel 1. 
Tabel 1. Hasil Pengukuran Total Organic Matter (TOM) pada Wadah Perlakuan

\begin{tabular}{ccccc}
\hline \multirow{2}{*}{ Perlakuan } & \multicolumn{4}{c}{ Hasil Pengukuran Total Organic Matter (TOM) (mg/L) } \\
\cline { 2 - 5 } & D0 & D7 & D14 & D21 \\
\hline A & 63,10 & 96,63 & 142,90 & 158,72 \\
B & 63,10 & 115,44 & 143,94 & 178,89 \\
C & 63,10 & 128,78 & 148,01 & 181,43 \\
\hline
\end{tabular}

Hasil perhitungan laju filtrasi (FR) kerang hijau ( $P$. viridis) dalam menurunkan kandungan bahan organik selama 21 hari penelitian tersaji pada Tabel 2.

Tabel 2. Laju Filtrasi (FR) Kerang Hijau (P. viridis) dalam Menurunkan Kandungan Bahan Organik selama Penelitian

\begin{tabular}{cccc}
\hline \multirow{2}{*}{ Perlakuan } & \multicolumn{3}{c}{ Laju filtrasi (FR) kerang hijau (L/hari) } \\
\cline { 2 - 4 } & D7 & D14 & D21 \\
A & $-1,83 \pm 0,27^{\mathrm{a}}$ & $-0,62 \pm 0,21^{\mathrm{a}}$ & $1,31 \pm 0,39^{\mathrm{a}}$ \\
B & $-2,07 \pm 0,06^{\mathrm{a}}$ & $-0,56 \pm 0,17^{\mathrm{a}}$ & $0,96 \pm 0,22^{\mathrm{a}}$ \\
C & $-2,03 \pm 0,05^{\mathrm{a}}$ & $-0,57 \pm 0,17^{\mathrm{a}}$ & $1,06 \pm 0,09^{\mathrm{a}}$ \\
\hline
\end{tabular}

Berdasarkan Tabel 2. menunjukkan bahwa laju filtrasi (FR) kerang hijau (P. viridis) mengalami kenaikan. Penurunan bahan organik didapatkan dari selisih antara konsentrasi bahan organik sebelum difilter oleh kerang hijau ( $P$. viridis) dengan konsentrasi bahan organik setelah difilter oleh kerang hijau ( $P$. viridis). Penurunan bahan organik selama penelitian tersaji pada Tabel 3.

Tabel 3. Penurunan Bahan Organik selama Penelitian

\begin{tabular}{cccc}
\hline \multirow{2}{*}{ Perlakuan } & \multicolumn{3}{c}{ Penurunan Bahan Organik Hari ke- (mg/L) } \\
\cline { 2 - 4 } & D7 & D14 & D21 \\
\hline A & $-46,28$ & $-23,42$ & 44,92 \\
B & $-54,19$ & $-21,48$ & 36,58 \\
C & $-52,82$ & $-22,45$ & 40,75 \\
\hline
\end{tabular}

Hubungan antara laju filtrasi (FR) kerang hijau ( $P$. viridis) dengan periode pemeliharaan kerang hijau dianalisis menggunakan analisis regresi. Koefisien korelasi antara periode pemeliharaan kerang hijau $(P$. viridis) (X) dengan laju filtrasi kerang hijau (Y) sebesar 0,995. Persamaan garis regresinya sebagai berikut:

$$
\mathbf{Y}=\mathbf{- 3 , 5 7 0}+\mathbf{0 , 2 2 0} \mathbf{X}
$$

\section{Pertumbuhan dan kelulushidupan}

Hasil rerata laju pertumbuhan relatif (RGR) dan kelulushidupan (SR) udang windu ( $P$. monodon), serta pertumbuhan panjang mutlak (GR) dan kelulushidupan (SR) kerang hijau ( $P$. viridis) tersaji dalam Tabel 4.

Tabel 4. Rerata RGR dan SR Udang Windu (P. monodon) serta Rerata GR dan SR Kerang Hijau ( $P$. viridis) selama Penelitian

\begin{tabular}{lccc}
\hline \multirow{2}{*}{ Variabel Data } & \multicolumn{3}{c}{ Perlakuan } \\
\cline { 2 - 4 } & $\mathrm{A}$ & $\mathrm{B}$ & $\mathrm{C}$ \\
\hline RGR Udang windu (\%) & $12,32 \pm 1,02^{\mathrm{a}}$ & $12,46 \pm 0,81^{\mathrm{a}}$ & $13,68 \pm 1,28^{\mathrm{a}}$ \\
SR Udang windu (\%) & $92,50 \pm 6,61^{\mathrm{a}}$ & $76,67 \pm 11,81^{\mathrm{a}}$ & $95,83 \pm 3,82^{\mathrm{a}}$ \\
GR Kerang hijau (cm) & $0,39 \pm 0,06^{\mathrm{a}}$ & $0,43 \pm 0,04^{\mathrm{a}}$ & $0,46 \pm 0,08^{\mathrm{a}}$ \\
SR Kerang hijau (\%) & $91,11 \pm 4,16^{\mathrm{a}}$ & $96,67 \pm 3,33^{\mathrm{a}}$ & $96,67 \pm 3,33^{\mathrm{a}}$ \\
\hline
\end{tabular}

\section{Kualitas air}

Hasil pengukuran kualitas air harian seperti oksigen terlarut (DO), suhu, salinitas, dan pH pada media pemeliharaan udang windu (P. monodon) tersaji pada Tabel 5.

Tabel 5. Kisaran Parameter Kualitas Air di Media Pemeliharaan Udang Windu (P. monodon) selama Penelitian

\begin{tabular}{ccc}
\hline Variabel & Hasil & Kelayakan \\
\hline DO $(\mathrm{mg} / \mathrm{L})$ & $3,0-6,2$ & $\geq 4 \mathrm{mg} / \mathrm{L}^{\mathrm{a}}$ \\
Suhu $\left({ }^{\circ} \mathrm{C}\right)$ & $27,6-31,5$ & $>27^{\circ} \mathrm{C}^{\mathrm{a}}$ \\
Salinitas $(\mathrm{ppt})$ & $27-35$ & $26-32(\mathrm{~g} / \mathrm{L})^{\mathrm{a}}$ \\
$\mathrm{pH}$ & $8,42-9,37$ & $7,5-8,5^{\mathrm{a}}$ \\
Bahan organik substrat $(\%)$ & $8,97-13,37$ & $<5 \% \%^{\mathrm{a}}$ \\
Amonia $\left(\mathrm{NH}_{3}\right)(\mathrm{mg} / \mathrm{L})$ & $0,015-0,331$ & $\leq 0,1^{\mathrm{a}}$ \\
\hline
\end{tabular}


Hasil pengukuran kualitas air harian seperti oksigen terlarut (DO), suhu, salinitas, dan pH pada media pemeliharaan kerang hijau ( $P$. viridis) tersaji pada Tabel 6.

Tabel 6. Kisaran Parameter Kualitas Air di Media Pemeliharaan Kerang Hijau (P. viridis) selama Penelitian

\begin{tabular}{ccc}
\hline Variabel & Hasil & Kelayakan \\
\hline DO $(\mathrm{mg} / \mathrm{L})$ & $3,1-6,5$ & $2-12 \mathrm{mg}^{\mathrm{a}} \mathrm{L}^{\mathrm{a}}$ \\
Suhu $\left({ }^{\circ} \mathrm{C}\right)$ & $27,4-30,9$ & $26-32^{\circ} \mathrm{C}^{\mathrm{b}}$ \\
Salinitas $(\mathrm{ppt})$ & $27-34$ & $15-45 \mathrm{ppt}^{\mathrm{c}}$ \\
$\mathrm{pH}$ & $8,86-9,31$ & $7-9^{\mathrm{d}}$ \\
Bahan organik substrat $(\%)$ & $7,55-14,17$ & $<5 \%$ \\
Nitrat $\left(\mathrm{NO}_{3}\right)(\mathrm{mg} / \mathrm{L})$ & $0,017-0,200$ & $0,5 \mathrm{mg} / \mathrm{L}^{\mathrm{e}}$ \\
\hline
\end{tabular}

Keterangan : ${ }^{\text {a) }}$ Alfaro (2005)

b) Hickman (1992)

c) McGuire dan Stevely (2009)

d) Sreedevi et al. (2014)

e) PERMEN-KP (2016)

\section{Kelimpahan plankton}

Hasil pengukuran kelimpahan plankton pada media pemeliharaan kerang hijau ( $P$. viridis) dapat dilihat pada Tabel 7.

Tabel 7. Kelimpahan Plankton di Media Pemeliharaan Kerang Hijau (P. viridis) pada Perlakuan A selama Penelitian

\begin{tabular}{ccccc}
\hline \multirow{2}{*}{ Perlakuan } & \multicolumn{4}{c}{ Kelimpahan plankton hari ke- (ind/L) } \\
\cline { 2 - 5 } & 0 & 7 & 14 & 21 \\
\hline A & 77.240 & 1.083 .333 & 858.333 & 766.667 \\
B & 77.240 & 750.000 & 666.667 & 600.000 \\
C & 77.240 & 783.333 & 941.667 & 692.667 \\
\hline
\end{tabular}

\section{PEMBAHASAN}

\section{Laju filtrasi kerang hijau}

Semakin intensif sistem budidaya udang maka kepadatan udang dan input pakan yang digunakan pun semakin meningkat. Meningkatnya input pakan pada budidaya udang mengakibatkan sisa pakan yang tidak termakan dan sisa feses juga semakin meningkat. Penelitian ini menggunakan perlakuan kepadatan udang windu (P. monodon) yang berbeda $\left(20,60\right.$, dan $\left.100 \mathrm{ekor} / \mathrm{m}^{2}\right)$. Penggunaan kepadatan udang windu (P. monodon) yang berbeda bertujuan sebagai sumber bahan organik yang akan difilter kerang hijau $(P$. viridis). Berdasarkan hasil analisis ragam pada minggu pertama terdapat perbedaan kandungan bahan organik antar perlakuan, namun pada minggu kedua dan minggu ketiga kandungan bahan organik antar perlakuan tidak berbeda. Salah satu faktor yang mempengaruhi kandungan bahan organik yaitu sisa pakan dan feses udang tidak mengendap sebagai total organic matter (TOM), tetapi sisa pakan dan feses tersebut telah terdekomposisi menjadi nitrat $\left(\mathrm{NO}_{3}\right)$, nitrit $\left(\mathrm{NO}_{2}\right)$, dan amonia $\left(\mathrm{NH}_{3}\right)$. Hal tersebut sesuai dengan hasil penelitian Dzulqa et al. (2018) yang menyatakan bahwa semakin tinggi kepadatan udang windu $\left(20,60\right.$, dan 100 ekor/m $\left.{ }^{2}\right)$ konsentrasi nitrat $\left(\mathrm{NO}_{3}\right)$, nitrit $\left(\mathrm{NO}_{2}\right)$, dan amonia $\left(\mathrm{NH}_{3}\right)$ akan semakin meningkat. Menurut Nirmala et al. (2005) apabila pakan tidak dimanfaatkan secara efektif oleh udang maka akan terjadi peningkatan bahan organik di dasar tambak. Peningkatan bahan organik pada tambak akan meningkatkan laju dekomposisi bahan oganik secara aerob yang menghasilkan senyawa toksik amonia $\left(\mathrm{NH}_{3}\right)$.

Berdasarkan hasil analisis ragam bahwa sumber bahan organik yang berasal dari kepadatan udang windu (P. monodon) yang berbeda $\left(20.60\right.$, dan 100 ekor $\left./ \mathrm{m}^{2}\right)$ tidak berpengaruh nyata $(\mathrm{P}>0,05)$ terhadap laju filtrasi kerang hijau ( $P$. viridis) dalam menurunkan kandungan bahan organik. Minggu pertama dan kedua penelitian laju filtrasi (FR) kerang hijau ( $P$. viridis) rendah sehingga kandungan bahan organik pada media pemeliharaan kerang hijau atau biofilter mengalami peningkatan. Laju filtrasi kerang hijau ( $P$. viridis) yang rendah sementara kerang hijau ( $P$. viridis) tetap melakukan eksresi yang merupakan sumber bahan organik mengakibatkan konsentrasi bahan organik pada minggu pertama dan kedua meningkat. Laju filtrasi kerang hijau ( $P$. viridis) setiap minggunya mengalami peningkatan. Hal tersebut diduga berkaitan dengan pertumbuhan kerang hijau ( $P$. viridis) yang setiap minggunya mengalami peningkatan. Bertambahnya umur dan ukuran kerang hijau $(P$. viridis) mengakibatkan kebutuhan pakannya meningkat. Salah satu makanan tambahan bagi kerang hijau $(P$. viridis) bahan organik. Meningkatnya kebutuhan pakan kerang hijau ( $P$. viridis) mengakibatkan laju filtrasinya terhadap bahan organik juga semakin meingkat. Marwan et al. (2015) menyatakan bahwa kerang hijau merupakan organisme filter feeder, yaitu hewan yang cara mendapatkan pakannya dengan memompa air melalui rongga mantel sehingga mendapatkan partikel-partikel yang ada dalam air. Pakan utama kerang hijau yaitu mikroalga, sedangkan pakan 
tambahan berupa zat organik. Menurut Putra (2006) kecepatan filtrasi kerang hijau dipengaruhi oleh beberapa faktor diantaranya yaitu salinitas, ukuran kerang, kualitas air, dan bukaan cangkang kerang. Laju filtrasi merupakan volume air bebas partikel dalam satuan waktu. Kerang hijau melakukan filtrasi pada siang dan malam hari.

Konsentrasi bahan organik pada minggu ketiga di media pemeliharaan kerang hijau ( $P$. viridis) atau biofilter mengalami penurunan. Menurunnya konsentrasi bahan organik mengakibatkan hasil perhitungan laju filtrasi kerang hijau ( $P$. viridis) mengalami peningkatan. Laju filtrasi kerang hijau $(P$. viridis) perlakuan A berkisar antara $(-1,83 \pm 0,27)-1,31 \pm 0,39 \mathrm{~L} /$ hari, perlakuan B berkisar antara $(-2,07 \pm 0,06)-0,96 \pm 0,22 \mathrm{~L} /$ hari, dan perlakuan $\mathrm{C}$ berkisar antara $(-2,03 \pm 0,05)-1,06 \pm 0,09 \mathrm{~L} /$ hari (Tabel 1). Penurunan kandungan bahan organik pada minggu ketiga perlakuan A sebesar 44,92 mg/L, perlakuan B sebesar 36,58 mg/L, dan perlakuan C sebesar 39,84 mg/L. Nilai laju filtrasi kerang hijau $(P$. viridis) dalam menurunkan kandungan bahan organik tidak berbeda antar perlakuan. Hal ini diduga karena kepadatan kerang hijau $(P$. viridis) yang digunakan dalam penelitian sama, yaitu $30 \mathrm{ekor} / \mathrm{m}^{2}$ dan konsentrasi bahan organik yang berasal dari kepadatan udang windu yang berbeda pun tidak berbeda, sehingga kemampuan filtrasi kerang hijau tidak berbeda nyata. Fua dan La (2008) menyatakan bahwa bioremediator kerang darah memiliki peran dalam menurunkan tingkat pencemaran limbah organik tambak udang. Densitas kerang darah berpengaruh terhadap penurunan limbah organik tambak udang, ditandai dengan pertambahan panjang dan berat kerang serta laju pertumbuhan spesifik. Terdapat korelasi antara lama waktu remediasi dengan penurunan parameter kualitas air limbah tambak udang.

Berdasarkan hasil analisis regresi didapatkan hasil nilai koefisien korelasi (r) sebesar 0,995, nilai $\mathrm{R}^{2}$ sebesar 0,990 dan persamaan regresi $\mathrm{Y}=0,220 \mathrm{X}-3,56$. Nilai koefisien korelasi (r) sebesar 0,995 menunjukkan bahwa terdapat korelasi yang sangat kuat antara periode pemeliharaan kerang hijau ( $P$. viridis) dengan laju filtrasinya. Nilai $\mathrm{R}^{2}$ sebesar 0,990 artinya bahwa $99 \%$ periode pemeliharaan kerang hijau ( $P$. viridis) berpengaruh terhadap laju filtrasi kerang hijau ( $P$. viridis), sementara 1\% dipengaruhi oleh faktor lain. Sugiyono (2011) menyatakan bahwa interval korelasi $0,00-0,199$ korelasinya sangat rendah, 0,20 - 0,399 korelasinya rendah, 0,40 - 0,599 korelasinya sedang, 0,60 - 0,799 korelasinya kuat, dan 0,80-1,00 nilai korelasinya sangat kuat.

\section{Laju pertumbuhan relatif (RGR) udang windu}

Berdasarkan hasil penelitian bahwa bahan organik dari sumber limbah yang berasal dari kepadatan udang windu ( $P$. monodon) yang berbeda yang telah difiltrasi kerang hijau $(P$. viridis) tidak berpengaruh $(\mathrm{P}>0,05)$ terhadap laju pertumbuhan relatif (RGR) udang windu ( $P$. monodon). Nilai rata - rata laju pertumbuhan relatif (RGR) perlakuan A sebesar 12,32 $\pm 1,02 \%$, perlakuan B sebesar 12,46 $\pm 0.81 \%$, dan perlakuan C sebesar $13,98 \pm 1,53 \%$. Nilai laju pertumbuhan relatif (RGR) udang windu ( $P$. monodon) tidak berbeda nyata diduga karena penggunaan kerang hijau ( $P$. viridis) sebagai biofilter mampu menciptakan kualitas yang dapat ditolerir udang windu ( $P$. monodon). Nilai laju pertumbuhan relatif udang windu ( $P$. monodon) tergolong rendah dibandingkan dengan hasil penelitian yang dilakukan oleh Evania (2018). Hasil penelitian menunjukkan bahwa udang windu $(P$. monodon) yang dibudidayakan dengan kerang hijau ( $P$. viridis) dengan kepadatan $30 \mathrm{ekor} / \mathrm{m}^{2}$ menggunakan

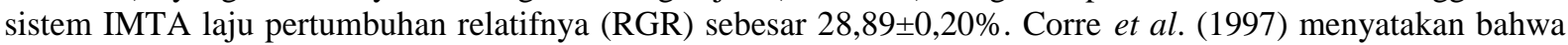
pertumbuhan dan kelulushidupan udang windu yang dibudidayakan dengan kerang ataupun tanpa kerang hijau tidak memberikan hasil yang signifikan.

Laju pertumbuhan relatif (RGR) udang windu ( $P$. monodon) pada minggu pertama baik perlakuan A, B maupun $\mathrm{C}$ pertumbuhannya lebih tinggi dibandingkan pada minggu kedua dan ketiga. Hal ini disebabkan nilai salinitas pada minggu kedua maupun ketiga nilainya lebih tinggi dibandingkan pada minggu pertama. Salinitas yang tinggi akan menghambat proses molting pada udang sehingga pertumbuhan udang pun menjadi lambat. Hal ini sesuai dengan pernyataan Syukri (2016) yang menyatakan bahwa perlakuan salinitas 25 ppt dan 30 ppt baik untuk proses molting yang dapat memperlancar proses osmoregulasi. Proses omsoregulasi ini menyebabkan terjadinya pertukaran garam-garam air laut ke dalam cairan tubuh udang. Salinitas yang tinggi $>35$ ppt dapat menghambat pertumbuhan udang karena proses molting sulit dilakukan yang berakibat pada kematian udang windu. Pertumbuhan udang pada salinitas yang rendah lebih tinggi dibandingkan dengan udang yang dipelihara pada salinitas yang tinggi, karena penyerapan air pada saat pergantian kulit (molting) tinggi. Hal tersebut akan mengakibatkan tubuh mengembang lebih tinggi dibandingkan dengan salinitas tinggi. Indikator dari pertumbuhan udang yaitu pergantian kulit atau molting. Semakin cepat udang berganti kulit berarti pertumbuhan udang pun semakin cepat.

\section{Kelulushidupan (SR) udang windu}

Hasil analisis ragam menunjukkan bahwa bahan organik yang berasal dari kepadatan udang windu $(P$. monodon) yang berbeda yang telah difiltrasi kerang hijau $(P$. viridis $)$ tidak berpengaruh nyata $(\mathrm{P}>0,05)$ terhadap kelulushidupan udang windu (P. monodon). Nilai kelulushidupan (SR) perlakuan A sebesar 92,50 $\pm 6,61$, perlakuan

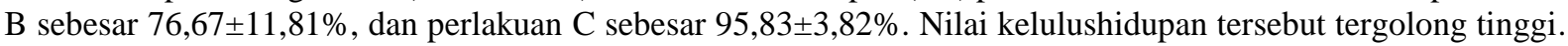
Berdasarkan hasil penelitian yang dilakukan oleh Evania (2018) udang windu yang dibudidayan dengan kerang hijau menggunakan sistem IMTA menghasilkan kelulushidupan tertinggi sebesar $80 \%$.

Tingkat kelulushidupan udang windu (P. monodon) juga dipengaruhi oleh faktor biotik dan abiotik. Salah satu contoh faktor abiotik yaitu kualitas air pada media budidaya. Walaupun kandungan oksigen terlarut (DO) berada dibawah baku mutu yang sudah ditetapkan namun nilainya masih dalam kondisi yang dapat ditolerir oleh udang windu ( $P$. monodon) sehingga tidak meyebabkan kematian udang. Cahyono (2009) menyatakan bahwa 
tinggi rendahnya kelulushidupan dalam budidaya dipengaruhi oleh faktor biotik dan faktor abiotik. Faktor biotik diantaranya yaitu faktor fisika dan faktor kimia perairan atau sering disebut dengan kualitas air. Kualitas air yang baik akan mempengaruhi proses fisiologi dalam tubuh udang berjalan dengan baik, sehingga pertumbuhan dan kelulushidupan udang pun akan semakin tinggi.

\section{Pertumbuhan kerang hijau}

Rata- rata pertumbuhan panjang mutlak kerang hijau ( $P$. viridis) pada perlakuan A sebesar $0,39 \pm 0,06 \mathrm{~cm}$,

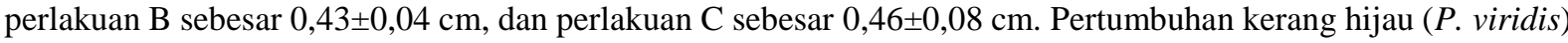
dipengaruhi oleh ketersediaan pakan dalam media budidaya. Pakan kerang hijau ( $P$. viridis) berupa plankton, bahan organik, dan sisa pakan maupun kotoran udang. Kelimpahan plankton dan kandungan bahan organik sebagai sumber pakan kerang hijau ( $P$. viridis) di semua perlakuan cukup tinggi, namun pertumbuhan kerang hijau tergolong rendah. Marwan et al. (2015) menyatakan bahwa mikroalga merupakan makanan utama kerang hijau, sedangkan makanan tambahan berupa zat organik. Sara et al. (2009) menambahkan bahwa kerang dapat memanfaatkan partikel organik yang berasal dari limbah budidaya untuk meningkatkan pertumbuhannya. Limbah organik budidaya dapat dimanfaatkan sebagai sumber pakan bivalvia sepeti kerang. Soon dan Ransangan (2014) menyatakan bahwa pertumbuhan bivalvia dapat dibedakan menjadi dua, yaitu pertumbuhan cangkang dan pertumbuhan tubuh. Panjang cangkang kerang tidak tentu mencerminkan isi dagingnya. Kerang selama memijah atau kekurangan pakan akan memanfaatkan atau mengkonsumsi cadangan energi, sementara itu cangkangnya bisa terus tumbuh. Kerang hijau memiliki tingkat pertumbuhan yang tinggi hingga $6-10 \mathrm{~mm}$ per bulan.

Rendanya pertumbuhan kerang hijau ( $P$. viridis) pada semua perlakuan diduga disebabkan oleh kondisi media budidaya yang tidak sesuai dengan habitat kerang hijau $(P$. viridis $)$ di alam. Salah satu variabel yang penting dalam budidaya kerang hijau $(P$. viridis) adalah arus atau pergerakan air. Kerang hijau $(P$. viridis $)$ dipelihara di wadah terpal sehingga arus atau pergerakan airnya sangat rendah jika dibandingkan dengan habitat aslinya di alam. Hal ini diperkuat oleh Soon dan Ransangan (2014) yang menyatakan bahwa pertumbuhan bivalvia dipengaruhi oleh kondisi lingkungan seperti kekeruhan, kecepatan arus, suhu, salinitas, ketersediaan pakan, komposisi fitoplankton, dan persaingan ruang gerak. Kuat arus merupakan faktor penting yang menentukan ketersediaan pakan untuk budidaya kerang hijau. Kuat arus yang rendah tidak menguntungkan bagi pertumbuhan kerang hijau, sedangkan kuat arus yang tinggi juga dapat menyebabkan kerang hijau muda/juvenil sulit menempel pada tempat hidupnya.

Hasil analisis regresi didapatkan hasil nilai koefisien korelasi ( $\mathrm{r}$ ) sebesar 0,943 , nilai $\mathrm{R}^{2}$ sebesar 0,889 dan persamaan regresi $Y=7,293 X-2,069$. Nilai koefisien korelasi (r) sebesar 0,943 menunjukkan bahwa terdapat korelasi yang sangat kuat antara laju filtrasi kerang hijau $(P$. viridis) dengan pertumbuhan panjang mutlaknya. Nilai $\mathrm{R}^{2}$ sebesar 0,889 artinya bahwa $89 \%$ laju filtrasi kerang hijau ( $P$. viridis) berpengaruh terhadap pertumbuhan panjang mutlak kerang hijau ( $P$. viridis), sementara 11\% dipengaruhi oleh faktor lain. Sugiyono (2011) menyatakan bahwa interval korelasi $0,00-0,199$ korelasinya sangat rendah, 0,20 - 0,399 korelasinya rendah, 0,40 - 0,599 korelasinya sedang, 0,60 - 0,799 korelasinya kuat, dan 0,80-1,00 nilai korelasinya sangat kuat.

\section{Kelulushidupan (SR) kerang hijau}

Berdasarkan hasil penelitian rata-rata kelulushidupan kerang hijau ( $P$. viridis) pada perlakuan A sebesar $91,11 \pm 4,16 \%$, perlakuan B sebesar $96,67 \pm 3,33 \%$, dan perlakuan C sebesar $100 \pm 0 \%$. Salah satu faktor yang mempengaruhi kelulushidupan kerang hijau ( $P$. viridis) yaitu kepadatan yang digunakan. Kepadatan kerang hijau (P. viridis) yang digunakan pada penelitian ini sama yaitu $30 \mathrm{ekor} / \mathrm{m}^{2}$, sehingga persaingan ruang gerak maupun persaingan konsumsi oksigen antar perlakuan sama. Garr et al. (2011) menyatakan bahwa kepadatan berpengaruh terhadap sintasan, pertumbuhan, dan produksi Pomacea paludosa. Sagita et al. (2017) menambahkan bahwa kepadatan merupakan salah satu faktor yang berpengaruh terhadap kelulushidupan (SR) kerang hijau $(P$. viridis).

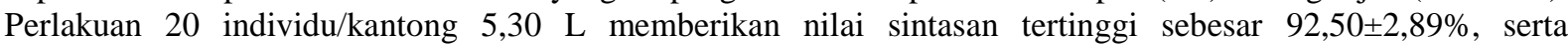
pertumbuhan spesifik berat (SGR W) sebesar $1,18 \pm 0,04 \%$ /hari, dan pertumbuhan spesifik panjang (SGR L) sebesar $0,86 \pm 0,01 \%$ /hari.

Secara keseluruhan nilai kelulushidupan kerang hijau $(P$. viridis) tergolong tinggi karena kelulushidupannya lebih dari $90 \%$. Tingginya nilai kelulushidupan kerang hijau dikarenakan jumlah pakan pada media pemeliharan yang melimpah baik berupa plankton maupun bahan organik. Cappenberg (2008) menyatakan bahwa kerang hijau ( $P$. viridis) tergolong organisme sesil yang hidupnya tergantung pada ketersediaan zooplankton, fitoplankton, dan material yang kaya kandungan bahan organik.

\section{Kualitas air \\ a. Pemeleliharaan udang windu}

Berdasarkan hasil penelitian bahwa nilai suhu, $\mathrm{pH}$, dan salinitas pada media pemeliharaan udang windu $(P$. monodon) layak digunakan untuk pembesaran udang windu ( $P$. monodon). Suhu pagi hari berkisar antara 27 $29^{\circ} \mathrm{C}$, sedangkan suhu sore hari berkisar antara $29-31^{\circ} \mathrm{C}$. Salinitasnya berkisar antara $27-35$ ppt. Derajat keasaman $(\mathrm{pH})$ berkisar antara 8,42 - 9,37. Menurut Boyd (1998) perairan payau biasanya memiliki nilai $\mathrm{pH} 8-$ 9 dan fluktuasi $\mathrm{pH}$ pada perairan payau lebih rendah dibandingkan dengan perairan tawar. $\mathrm{pH}$ yang baik untuk pertumbuhan ikan ataupun krustase berkisar antara $6-9$. Nilai $\mathrm{pH} 9-11$ pertumbuhan ikan ataupun udang akan lambat. Djunaedi et al. (2016) menambahkan bahwa nilai $\mathrm{pH}$ yang rendah $(6,4)$ akan menyebabkan udang menjadi keropos dan tampak lembek karena tidak dapat membentuk kulit baru. Jika nilai pH tinggi akan mengakibatkan peningkatan konsentrasi amonia $\left(\mathrm{NH}_{3}\right)$ yang secara tidak langsung dapat membahayakan kehidupan udang. 
Konsentrasi amonia $\left(\mathrm{NH}_{3}\right)$ berkisar antara 0,015 - 0,331 mg/L. Hasil tersebut kurang layak digunakan untuk budidaya udang. Berdasarkan PERMEN-KP No. 75 (2016) konsentrasi maksimal amonia $\left(\mathrm{NH}_{3}\right)$ pada pembesaran udang windu dengan sistem semi intensif dan intensif yaitu $\leq 0,1 \mathrm{mg} / \mathrm{L}$.

Kandungan oksigen terlarut (DO) pada media pemeliharaan udang windu ( $P$. monodon) berkisar antara 3,0 $-6,0 \mathrm{mg} / \mathrm{L}$. Nilai oksigen terlarut terendah pada pagi hari. Nilai tersebut tergolong rendah dan kurang layak digunakan untuk budidaya udang windu (P. monodon). Berdasarkan PERMEN-KP No. 75 (2016) bahwa oksigen terlarut (DO) yang layak untuk pemeliharaan udang windu $\geq 4 \mathrm{mg} / \mathrm{L}$. Boyd (1998) menyatakan bahwa efek dari rendahnya nilai oksigen terlarut dapat menyebabkan rendahnya pertumbuhan dan kutivan rentan terserang penyakit. Paparan konsentrasi oksigen terlarut $2-5 \mathrm{mg} / \mathrm{L}$ secara terus-menerus akan menyebabkan pertumbuhan yang lambat. Kandungan oksigen terlarut $5 \mathrm{mg} / \mathrm{L}$ sampai dengan saturasi merupakan konsentrasi yang optimal untuk pertumbuhan kultivan.

Nilai oksigen terlarut yang rendah berbanding terbalik dengan kandungan bahan organik baik di media pemeliharaan maupun di substrat. Kandungan bahan organik pada media budidaya maupun pada substrat tergolong tinggi. Rendahnya oksigen terlarut di media budidaya diduga oksigen terlarut digunakan untuk proses dekomposisi bahan organik sehingga nilainya menjadi rendah. Kandungan bahan organik substrat pada pemeliharaan udang windu (P. monodon) berkisar antara 9,76-12,43\%. Nilai tersebut tergolong tinggi karena karena nilainya melebihi baku mutu yang telah ditentukan. Berdasarkan PERMEN-KP No. 75 (2016), bahwa kandungan bahan organik yang layak untuk pemeliharaan udang windu ( $P$. monodon) skala intensif yaitu $<5 \%$.

\section{b. Pemeliharaan kerang hijau}

Berdasarkan hasil penelitian kandungan oksigen terlarut (DO), suhu, salinitas, $\mathrm{pH}$, dan nitrat $\left(\mathrm{NO}_{3}{ }^{-}\right)$pada media pemeliharaan kerang hijau $(P$. viridis) atau biofilter masih layak digunakan untuk budidaya kerang hijau $(P$. viridis). Kandungan bahan organik substrat berkisar antara 7,55-14,17\%. Tingginya kandungan bahan organik pada substrat diduga disebabkan oleh bahan organik dari sisa pakan, maupun feses udang yang mengendap di dasar perairan. Pada minggu pertama dan kedua penelitian kandungan bahan organik substrat mengalamani kenaikkan. Hal ini disebabkan oleh ketidakmampuan kerang hijau dalam menurunkun bahan organik pada minggu pertama dan kedua. Pada minggu ketiga kandungan bahan organik substrat mengalami penurunan hal ini berbanding lurus peningkatan laju filtrasi kerang hijau ( $P$. viridis) dalam menurunkan bahan organik. Putra (2006) menyatakan bahwa bahan organik partikel (padatan) akan mengendap pada sedimen dan sebagian ada yang melayang-layang di kolom perairan karena adanya gaya grafitasi. Bahan organik total terdiri dari bahan organik terlarut, tersuspensi (partikulat), koloid ataupun dalam bentuk yang lebih besar, dan dalam bentuk hidup seperti seston serta dalam bentuk mati seperti detritus dan tripton.

Plankton yang ditemukan selama penelitian terdiri dari enam filum fitoplankton meliputi Cyanophyta, Chlorophyta, Charophyta, Bacillariophyta, Hapthophyta dan Ciliophora, sedangkan zooplankton terdiri dari tiga filum meliputi Euglenozoa, Arthropodadan rotifer. Kelimpahan fitoplankton pada semua perlakuan didominasi oleh filum Bacillariophyta, sedangkan zooplankton tidak ada filum yang mendominasi. Berdasarkan hasil penelitian Basir et al. (2013), analisa fitoplankton pada area budidaya kerang hijau ( $P$. viridis) didapatkan hasil bahwa kelimpahan fitoplankton tertinggi dari kelas Bacillariophyceae dan Dinophyceae. Bacillariophyceae dan Dinophyceae banyak ditemukan di stasiun penelitian yang dekat dengan daratan. Fitoplankton dari kedua kelas ini dapat bertahan hidup pada perairan dengan kandungan nutrisi rendah maupun dengan kandungan nutrisi yang tinggi.

Hasil pengukuran kelimpahan plankton dari minggu pertama hingga minggu ketiga penelitian mengalami fluktuasi. Kelimpahan plankton perlakuan A pada minggu pertama sebesar 1.083.333 ind/L, minggu kedua sebesar 858.333 ind/L dan pada minggu ketiga sebesar 766.667 ind/L. Kelimpahan plankton perlakuan B pada minggu pertama sebesar 750.000 ind/L, minggu kedua sebesar $666.667 \mathrm{ind} / \mathrm{L}$ dan pada minggu ketiga sebesar 600.000 ind/L. Kelimpahan plankton perlakuan C pada minggu pertama sebesar 783.333 ind/L, pada minggu kedua sebesar 916.667 ind/L dan pada minggu ketiga sebesar $691.667 \mathrm{ind} / \mathrm{L}$. Melimpahnya plankon pada penelitian ini diduga karena kondisi perairan baik pH maupun suhu berada pada nilai yang optimal untuk mendukung pertumbuhan plankton. Wulandari et al. (2014) menyatakan bahwa kelimpahan fitoplankton yang tinggi di suatu stasiun diduga disebabkan oleh faktor lingkungan dari perairan yang mendukung mendukung kehidupan fitoplankton. Kandungan oksigen terlarut serta nutrien yang mencukupi merupakan salah satu faktor penyebab tingginya kelimpahan fitoplankton. Hasil pengukuran nitrat $\left(\mathrm{NO}_{3}\right)$ pada berlakuan A berkisar antara $0,034-0,068 \mathrm{mg} / \mathrm{L}$, pada perlakuan B berkisar antara $0,19-0,20 \mathrm{mg} / \mathrm{L}$ dan pada perlakuan $\mathrm{C}$ berkisar antara 0,017 - 0,059 mg/L. Nilai tersebut bukan merupakan nilai yang optimum untuk mendukung kehidupan fitoplankton, namun belum menjadi faktor pembatas bagi kehidupan fitoplankton. Menurut Wardoyo (1982) kandungan nitrat $\left(\mathrm{NO}_{3}\right)$ yang optimal untuk pertumbuhan fitoplankton yaitu berkisar antara $0,9-3,5 \mathrm{mg} / \mathrm{L}$.

Kelimpahan fitoplankton juga dapat mempengaruhi fluktuasi oksigen terlarut di media budidaya. Kelimpahan plankton yang tinggi dapat menyebabkan menurunnya kandungan oksigen terlarut pada malam hari sampai pagi hari. Kelimpahan plankton dari awal penelitian hingga akhir penelitian cenderung menurun. Menurut Boyd (1998) kelimpahan plankton merupakan faktor yang mempengaruhi dinamika oksigen terlarut pada kolam budidaya. Sedimen dasar juga memerlukan oksigen untuk dekomposisi bahan organik. Tingkat konsumsi oksigen akan semakin meningkat seiring dengan meningkatnya waktu budidaya. Kelimpahan plankton dipengaruhi oleh 
kelimpahan nutrien yang berasal dari limbah budidaya berupa bahan organik dan anorganik serta pakan yang tidak termakan. Konsentrasi oksigen terlarut dipengaruhi oleh kelimpahan plankton

\section{KESIMPULAN DAN SARAN \\ Kesimpulan}

Berdasarkan hasil penelitian dapat disimpulkan sebagai berikut :

1. Laju filtrasi kerang hijau ( $P$. viridis) pada perlakuan A berkisar antara $(-1,83)-1,31 \mathrm{~L} /$ hari penurunan bahan organik sebesar 44,92 mg/L, perlakuan B berkisar antara $(-2,07)-0,96 \mathrm{~L} /$ hari penurunan bahan organik sebesar 36,58 mg/L, dan perlakuan C berkisar antara $(-2,03)-1,06 \mathrm{~L} /$ hari penurunan bahan organik sebesar $39,84 \mathrm{mg} / \mathrm{L}$;

2. Media hasil filtrasi kerang hijau (P. viridis) tidak berpengaruh nyata terhadap laju pertumbuhan relatif (RGR) udang windu ( $P$. monodon) dan kelulushidupan udang windu ( $P$. monodon). Laju pertumbuhan relatif (RGR) udang windu ( $P$. monodon) perlakuan A sebesar 12,32 $\pm 1,02 \%$, perlakuan B sebesar

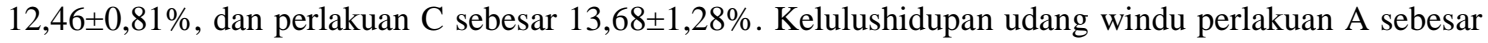
$92,50 \pm 6,61 \%$, perlakuan B sebesar $76,67 \pm 11,81 \%$, dan perlakuan C sebesar $95,83 \pm 3,82 \%$.

\section{Saran}

Berdasarkan hasil penelitian saran yang dapat diberikan yaitu sebaiknya pada wadah pemeliharaan kerang hijau atau biofilter aerasi yang digunakan lebih besar sehingga dapat menghasilkan pergerakan air yang lebih besar. Fungsi pergerakan air yang lebih besar yaitu agar distribusi bahan organik dapat merata di seluruh media budidaya sehingga filtrasi kerang hijau ( $P$. viridis) terhadap bahan organik lebih maksimal.

Ucapan Terima Kasih

Terima kasih penulis ucapkan kepada PASMI (Project for Aquaculture Supporting Mangrove Forest in Indonesia) yang telah menyumbang dana untuk penelitian.

\section{DAFTAR PUSTAKA}

Akhrari, H. 2013. Kemampuan Serap Rumput Laut Gracilaria sp Terhadap Nitrogen Hasil Buangan Limbah Budidaya Udang Windu Penaeus monodon dalam Sistem Polikultur. [Skripsi]. Institut Pertanian Bogor, Bogor, $53 \mathrm{hlm}$.

Alfaro, A.C. 2005. Effect of Water Flow and Oxygen Concentration on Early Settlement of the New Zealand Green-lipped Mussel Perna canalicus. Journal Aquaculture., 285-294.

Basir, A., R. Widiarti and W. Wardhana. 2013. Spatial Analysis on Phytoplankton in Green Mussel Aquaculture Area, Kamal Muara, North Jakarta. The 3rd International Conference on Biological Science 2013., 2 (2015): 203-212.

Boyd. 1998. Water Quality for Pond Aquaculture. Pub. International Center for Aquaculture and Aquatic Environments, Alabama Agricultural Experiment Station, Auburn University, 37 p.

Budiardi, T., R.D. Salleng dan N.B.P. Utomo. 2005. Penokolan Udang Windu, Penaeus monodon Fab. dalam Hapa Pada Tambak Intensif dengan Padat Tebar Berbeda. Jurnal Akuakultur Indonesia., 4 (2): 153158.

Cappenberg, H.A.W. 2008. Beberapa Aspek Biologi Kerang Hijau Perna viridis Linnaeus 1758. Jurnal Oseanografi LIPI., 33(1): 33-40.

Cahyono, B. 2009. Budidaya Biota Air Tawar. Kanisius. Yogyakarta.

Corre, K.G., V.L. Corre and W. Gallardo. 1997. The Growth, Survival and Production of Shrimp (Penaeus monodon) Cultured with Green Mussel (Perna viridis) in Semi-intensive Ponds. UPV Journal Of Natural Sciences., 2(1):1-8.

Craba, R., Y. Avnimelechc, T. Defoirdt, P. Bossier and W. Verstraete. 2007. Nitrogen Removal Techniques in Aquaculture for a Sustainable Production. Journal Aquaculture., 1(270): 1-14.

Djunaedi, A., H. Susilo dan Sunaryo. 2016. Kualitas Air Media Pemeliharaan Benih Udang Windu (Penaeus monodon Fabricius) dengan Sistem Budidaya yang Berbeda. Jurnal Kelautan Tropis., 19(2): 171-178.

Effendie, M.I. 1997. Biologi Perikanan. Yayasan Pustaka Nusantara, Yogyakarta, 163 hlm.

Dzulqa, R.S. 2018. Laju Penyerapan Amonia, Nitrtit dan Nitrat oleh Glacilaria verrucosa sebagai Biofilter serta Dampaknya Terhadap Pertumbuhan dan Kelulushidupan Udang Windu (Penaeus monodon).[Skripsi].

Evania, C. 2018. Performa Pertumbuhan Udang Windu (Penaeus monodon) yang Dibudidayakan Bersama Kerang Hijau (Perna viridis) dengan Sistem IMTA. [Skripsi]. Universitas Diponegoro, Semarang, 85 hlm

Fua dan J. La. 2008. Penurunan Tingkat Pencemaran Limbah Organik Tambak Udang Menggunakan Kerang Darah (Anadara granosa L.) sebagai Bioremediator. [Tesis]. Sekolah Pascasarjana, Universitas Gadjah Mada, Yogyakarta (abstrak).

Garr, A.L., Lopez. H, Pierce. R and M. Davis. 2011. the Effect of Stocking Density and Diet on The Growth and Survival of Culture Florida Apple Snails, Pomacea Paludosa. Journal Aquaculture., 311, 139-145.

Hickman, R.W. 1992. Mussel cultivation. in Gosling, E. (Ed.) (2003). the Mussel Mytilus: Ecology, Physiology, Genetics and Culture. Amsterdam. Elsevier. 
Hold, S.L and M.D. Edwards. 2014. Cost-effective IMTA: a Comparison of the Production Efficiencies of Mussels and Seaweed. J. Appl Phycol., 26: 933-945.

Lante, S., Usman dan A. Laining. 2015. Pengaruh Kadar Protein Pakan Terhadap Pertumbuhan dan Sintasan Udang Windu, Penaeus monodon Fab.Transveksi. Jurnal Perikanan., 17(1): 10-17.

Liliandari, P dan Aunurohim. 2013. Kecepatan Filtrasi Kerang Hijau Perna viridis Terhadap Chaetoceros sp dalam Media Logam Tercemar Kadmium. Jurnal Sains dan Seni Pomits., 2(2): 2337-3520.

Mangampa, M. 2012. Polikultur Udang Windu (Penaeus monodon), Bandeng (Chanos chanos), Nila Srikandi (Oreochromis aureus $x$ O. niloticus) dan Rumput Laut (Gracilaria verrucosa) di Tambak Tanah Sulfat Masam (TSM). Jurnal Riset Akuakultur. 4(1):1-13.

Marwan, A.H., N. Widyorini dan M. Nitisupardjo. 2015. Hubungan Total Bakteri dengan Kandungan Bahan Organik Total di Muara Sungai Babon, Semarang. Diponegoro Journal Of Maquares., 4(3):170-179.

McGuire, M and J. Stevely. 2009. Invasive Species of Florida's Coastal Waters: the Asian Green Mussel (Perna viridis). University of Florida. Florida.

Muslim. 2013. Pengurangan Racun Amonia, Bahan Organik dan Padatan Tersuspensi di Media Budidaya Udang Galah dengan Biofilter dari Bahan Genteng Plastik Bergelombang. 2013. Jurnal Bumi Lestari., 13(1): 79-90.

Nirmala, K., E. Yuniar dan T. Budiardi. 2005. Produktivitas dan Parameter Kimia Dasar Tambak Budidaya Udang Windu Penaeus Monodon Fab. Berumur 1 Dan 3 Tahun. Jurnal Akuakultur Indonesia., 4 (1): 5-11.

Palayukan, R.A., Badraeni., Y.A. Hasni dan T. Ambo. 2016. Efektivitas Rumput Laut Gracilaria sp. sebagai Bioremediator Perubahan $\mathrm{N}$ dan $\mathrm{P}$ dalam Bak Pemeliharaan Udang Vaname Litopenaeus vannamei. Jurnal Rumput Laut Indonesia., 1(2): 88-93.

Pedoman Umum Pembesaran Udang Windu (Penaeus monodon) dan Udang Vaname (Litopenaeus vannamei). PERMEN No. 75. 2016. $43 \mathrm{hlm}$.

Putra, S., A. Arianto, E. Efendi, Q. Hasani dan H. Yulianto. 2016. Efektifitas Kijing Air Tawar (Pilsbryoconcha exilis) sebagai Biofilter dalam Sistem Resirkulasi Terhadap Laju Penyerapan Amoniak dan Pertumbuhan Ikan Lele Sangkuriang (Clarias gariepinus). Jurnal Rekayasa dan Teknologi Budidaya Perairan., 4(2): 497-506.

Putra, W.S. 2006. Laju Filtrasi Kerang Hjjau (Perna viridis L. 1758) dalam Mereduksi Bahan Tersuspensi. [Skripsi]. Institut Pertanian Bogor, Bogor, $77 \mathrm{hlm}$.

Riisgard, H.U. 2001. on Measurement of Filtration Rate in Bivalve-the Story Road to Reliable Data: Review and Intepretation Data. Mar Ecol. Prog. Ser. 221: 275-291.

Sagita, A., R. Kurnia dan Sulistiono. 2017. Budidaya Kerang Hijau (Perna viridis L.) dengan Metode dan Kepadatan Berbeda di Perairan Pesisir Kuala Langsa, Aceh. Jurnal Riset Akuakultur., 12(1): 57-68.

Sara, G. A., Zenone dan A. Tomasello. 2009. Growth of Mytilus Galloprovincialis (Mollusca, Bivalvia) Close to Fish Farms: A Case of Integrated Multi-Trophic Aquaculture Within the Tyrrhenian Sea. Hydrobiologia. 636:129-136.

Sugiyono. 2011. Metode Penelitian Kuantitatif, Kualitatif dan R\&D. Afabeta, Bandung 83 hlm.

SNI 03-2831-1992. Metode Pengujian Kadar Bahan Organik dalam Tanah dengan Pembakaran. Badan Standarisasi Nasional, Jakarta. $17 \mathrm{hlm}$.

SNI-06-6989.22-2004. Cara Uji Nilai Permanganat secara Titrimetri. Badan Standarisasi Nasional, Jakarta. 10 hlm.

Soon, T.K dan J. Ransangan. 2014. A Review of Feeding Behavior, Growth, Reproduction and Aquaculture Site Selection for Green-Lipped Mussel, Perna viridis. Advances in Bioscience and Biotechnology., 462 469.

Sreedevi, P.R., V. Uthayakumar, R. Jayakumar, P. Joseph, D.S. Kumar dan V. Ramasubramanian. 2014. Comparative Valuation of On-bottom and Off Bottom Mussel (Perna viridis) Culture as a Small Scale Enterprise in Chettuva Estuary at Kerala India. World Journal of Fish and Marine Science., 6: 487-493.

Syukri, M. 2016. Pengaruh Salinitas Terhadap Sintasan dan Pertumbuhan Larva Udang Windu (Penaeus Monodon). Jurnal Galung Tropika., 5(2): 86-96.

Takeuchi, T. 1988. Laboratory Work-chemical Evaluation of Dietary Nutriens. in: Watanabe, T. Edo, Fish Nutrition and Mariculture, JICA, Tokyo Univ, Fish, 179-229 p.

Wardoyo, S.T.H. 1982. Pengelolaan Kualitas Air Pusat Studi Pengelolaan Sumberdaya Lingkungan. Institut Pertanian Bogor, Bogor.

Wulandari, D.Y., N.T.M. Pratiwi. 2014. Distribusi Spasial Fitoplankton di Perairan Pesisir Tangerang. Jurnal Ilmu Pertanian Indonesia (JIPI)., 19(3): 156-162.

Wulandari, T., N. Widyorini dan P. Wahyu. 2015. Pengelolaan Kualitas Air dengan Kandungan Bahan Organik, $\mathrm{NO}_{2}$ dan $\mathrm{NH}_{3}$ pada Budidaya Udang Vannamei (Litopenaeus vannamei) di Desa Keburuhan Purworejo. Journal of Maquares Management of Aquatic Resources., 4(3): 42-48. 